\title{
PENATAAN PEDAGANG KAKI LIMA: RESILIENSI USAHA DI MASA PANDEMI
}

\author{
Syaeful Bakhri \\ Institut Agama Islam Negeri Syekh Nurjati Cirebon \\ Email: SultanO1aulia@yahoo.com
}

\begin{abstract}
The purpose of this study was to find a strategy for structuring street vendors as well as conducting research related to the factors that affect the resilience of street vendors' business during the covid-19 pandemic. The research method uses descriptive qualitative methods with SWOT analysis which is used to explore or evaluate the strengths, weaknesses, opportunities, and threats to existing conditions in analyzing the resilience strengths of street vendors during the covid-19 pandemic. Based on the results of the study, it is known that in structuring street vendors, local government support is needed through regulatory strategies related to structuring and empowerment whose implementation needs to be more assertive to minimize weaknesses by taking advantage of resource opportunities that exist in street vendors. As for maintaining the business existence of street vendors during the COVID-19 pandemic, street vendors can upgrade service patterns that are adapted to the conditions for implementing social distancing policies by the government, such as providing take away along with pedestrians, using information technology as a means of marketing innovation. To be able to compete with the increasingly competitive competition.
\end{abstract}

Keywords: Street Vendors, Business Resilience, and Covid-19 Pandemic.

\begin{abstract}
Abstrak
Tujuan penelitian ini adalah untuk menemukan strategi penataan PKL sekaligus melakukan penelitian terkait fakotr - faktor yang mempengaruhi resiliensi usaha PKL di tengah pandemi covid-19. Metode penelitian menggunakan metode kualitatif deskriptif dengan analisis SWOT yang digunakan untuk menggali atau mengevaluasi terhadap kekuatan, kelemahan, peluang, dan ancaman terhadap kondisi eksisting dalam menganalisis kekuatan resiliensi para pedagang kaki lima di tengah pandemi covid-19. Berdasarkan hasil penelitian, diketahui bahwa dalam penataan PKL perlu dukungan pemerintah daerah melalui strategi regulasi terkait penataan dan pemberdayaan yang implementasinya perlu lebih tegas untuk meminimalisasi kelemahan dengan memanfaatkan peluang sumber daya yang ada pada PKL. Adapun untuk menjaga eksistensi usaha para pelaku PKL di tengah masa pandemi covid-19, para pelaku PKL dapat melakukan upgrade pola layanan yang disesuaikan dengan kondisi pemberlakukan kebijakan social distancing oleh pemerintah, seperti halnya penyediaan take away disepanjang pedestrian, pemanfaatan teknologi informasi sebagai sarana inovasi pemasaran agar dapat bersaing dengan persaingan yang semakin kompetitif.
\end{abstract}

Kata Kunci: Pedagang Kaki Lima, Resiliensi Usaha, dan Pandemi Covid-19. 


\section{PENDAHULUAN}

Pedagang kaki lima (PKL) merupakan salah satu bentuk kegiatan informal (Budi, 2016) yang mana dalam aktivitasnya, kegiatan di sektor informal seringkali memanfaatkan fasilitas umum yang tidak diperuntukkan sebagai media berjualan (Widjajanti, 2016) seperti trotoar jalan, badan jalan dan emperan toko. Sehingga tidak heran, jika di beberapa kota besar, pedagang kaki lima identic dengan masalah kemacetan lalu lintas, kesemwarutan dan telah menimbulkan "kesan" mengganggu karena dapat menimbulkan pencemaran (kebersihan), kesehatan dan keamanan bagi lingkungan sekitar (Wiweka et al., 2018).

Namun bagi sekelompok masyarakat, PKL justru menjadi solusi untuk mendapatkan barang dengan murah. Menjadi manifestasi dari situasi pertumbuhan kesempatan tenaga kerja (Astuti et al., 2017) terutama bagi mereka yang tidak terserap di sektor formal kerja (Usman, 2006). Kehadiran PKL di ruang kota juga dapat meningkatkan vitalitas bagi kawasan yang ditempatinya serta berperan sebagai penghubung kegiatan antara fungsi pelayanan kota yang satu dengan yang lainnya. Selain itu, PKL juga memberikan pelayanan yang mudah dan cepat untuk mendapatkan barang yang mereka butuhkan (Sastrawan, 2015). Dengan kata lain meskipun keberadaan PKL dianggap menimbulkan berbagai masalah perkotaan, namun di sisi lain PKL memiliki manfaat ekonomi bagi sebagian masyarakat (Astuti et al., 2017) terlebih di masa pandemic covid seperti sekarang ini.

Sebagaimana yang kita ketahui, pandemic covid-19 yang terjadi pada akhir tahun 2019 hingga saat ini (Zulhijahyanti et al., 2021) telah berdampak pada seluruh sektor kehidupan (Dewi Amaliah, 2020) utamanya dalam hal ini adalah kontraksi ekonomi di berbagai Negara di dunia termasuk Indonesia. Munculnya kebijakan pembatasan aktivitas masyarakat sebagai upaya penanganan pandemi telah menimbulkan kerugian ekonomi yang signifikan secara nasional (Astuti \& Qalyubi,
2021). Salah satu sektor ekonomi yang mengalami guncangan selama adanya pandemic covid-19 yaitu sektor UMKM (Bakhri \& Futiah, 2020) dan satu diantaranya adalah para PKL yang merasakan dampak signifikan dari pandemic covid-19 (Zulhijahyanti et al., 2021). Hal ini dipertegas dengan pernyataan (Hutasuhut, 2020) berdasarkan hasil penelitiannya yang menyatakan bahwa PKL merupakan bagian masyarakat yang paling merasakan dampak pandemi Covid-19. Maka demikian diperlukan upaya resiliensi para pelaku usaha agar dapat bertahan di masa sulit yakni masa pandemic covid-19 (Indah et al., 2021).

Resiliensi sendiri merupakan bentuk ketahanan di tengah konflik keberadaan pedagang kaki lima, pemerintah tentu saja perlu meninjau sisi positif sektor informal PKL sebagai harapan penyumbang perekonomian dan penyerapan tenaga kerja yang besar. Oleh sebab itu, selain bertujuan untuk menemukan strategi penataan PKL, penulis juga bertujuan untuk melakukan penelitian terkait apa saja yang menjadi faktor dalam mempengaruhi keberlangsungan usaha PKL di tengah masa pandemic covid-19.

\section{LITERATURE REVIEW}

Penelitian terkait dengan penataan PKL sudah banyak dilakukan, namun sejauh ini belum ada yang melakukan di lingkup daerah Kabupaten Cirebon. Namun begitu, masih terdapat beberapa penelitian terdahulu yang dapat dijadikan sebagai literature review terkait penataan PKL dan penggunaan analisis SWOT sebagai metode analisis penelitian yang akan penulis lakukan, antara lain:

1. (Mashudi et al., 2019)

Masyarakat masih membutuhkan PKL, namun diperlukan penataan agar tidak mengganggu akses pejalan kaki dan tidak menimbulkan kesemrawutan kota. Hasil dari analisis SWOT diperoleh alternatif strategi SO yaitu melakukan review kebijakan tentang PKL, WO yaitu meningkatkan kemitraan Pemerintah dengan PKL, ST yaitu memfasilitasi ruang usaha dan rasa aman 
berusaha dan strategi WT, yaitu mengoptimalkan sarana prasarana kota.

2. (Komara et al., 2020)

Berdasarkan hasil temuannya, penulis menjelaskan bahwa masyarakat pelaku PKL perlu melakukan kreativitas dan inovasi dalam menciptakan produk atau strategi pemasaran di tengah situasi ketidakpastian. Pelaku usaha perlu memaksimalkan produk bersih/higienis, ramah lingkungan, optimal memanfaatkan keunggulan alam Indonesia yang subur dan pemasaran dengan pola digital marketing untuk menjangkau pasar yang lebih luas yang tetap bertahan ketika sosial distancing diterapkan. Mencari sumber permodalan murah yang ditawarkan oleh investor, pemerintah atau lembaga keuangan lainya untuk membangkitkan kembali usaha. Melakukan negosiasi dan restrukturisasi kredit yang ada agar dapat memberikan ruang gerak usaha yang cukup untuk kembali bangkit ketika pandemi covid-19 usai.

3. (Qiptiyah, 2021)

Penelitian ini menghasilkan temuan bahwa tersedianya sarana transportasi guna distribusi mengunjungi konsumen di masa social distancing mampu memberikan peluang dalam proses pendistribusian barang dagangan. Serta continue upgrade atau pembaharuan informasi yang berkelanjutan mengenai ketersediaan barang yang dibutuhkan oleh konsumen sebagai tambahan atas produk yang nantinya akan dijual belikan akan menjadi kekuatan para pelaku PKL demi bertahan di masa-masa sulit adanya pandemic covid-19.

4. (Syariah \& Widiastuti, 2017)

Startegi dalam penataan PKL berdasarkan analisis SWOT adalah dengan mengatur lokasi, jenis, waktu dan desain tempat penjualan, adapun untuk konsep penataan parkir dapat dilakukan dengan mengatur waktu dan titik lokasi perparkiran. Selain itu, peneliti juga menunjukkan perlu adanya jalur penghubung antar ruang parkir,
PKL dan pertokoan yang nyaman dan aman untuk keberlanjutan.

5. (Astuti \& Qalyubi, 2021)

Penelitian ini menghasilkan temuan bahwa strategi yang dapat digunakan untuk keberlanjutan usaha PKL di masa pandemic covid harus berupaya untuk menciptakan sumber pendapatan baru yang dapat menambah pendapatan. Hal ini dapa dilakukan dengan cara menambahkan fasilitas layanan ojek, atau pengadaan jasa antar makanan atau belanjaan secara online.

6. (Pratama et al., 2021)

Strategi yang dapat dilakukan oleh para pelaku UMKM dan PKL dalam hal memperluas jangkauan pasar di tengah kebijakan pencegahan penyebaran covid-19 adalah dengan penerapan Contactless Business. Contactless Business ini dapat diaplikasikan melalui penggunaan teknologi di bidang pemasaran untuk memperluas jangkauan pasar. Penggunaan teknologi secara konkrit untuk melakukan promosi adalah dengan media promosi melalui media sosial dan online delivery sharing system.

7. (Syariah \& Widiastuti, 2017)

Startegi dalam penataan PKL berdasarkan analisis SWOT adalah dengan mengatur lokasi, jenis, waktu dan desain tempat penjualan, adapun untuk konsep penataan parkir dapat dilakukan dengan mengatur waktu dan titik lokasi perparkiran. Selain itu, peneliti juga menunjukkan perlu adanya jalur penghubung antar ruang parkir, PKL dan pertokoan yang nyaman dan aman untuk keberlanjutan.

8. (Wiweka et al., 2018)

Penelitian ini menghasilkan temuan bahwa penataan PKL dapat dilakukan dengan cara zona pemanfaatan, terutama yang terkait dengan sentra kuliner yang bercirikan kebudayaan. Dimana pedagang-pedagang yang dilibatkan merupakan masyaraat lokal atau PKL yang telah ada sebelumnya. Dengan desain ini penataan PKL dapat lebih 
terkelola dan menjadi daya tarik dan mendukung kegiatan wisata di suatu daerah.

\section{METODE PENELITIAN}

Analisis ini dilakukan dengan pendekatan kualitatif deskriptif, didalamnya peneliti menyusun sistematis data yang diperoleh berdasarkan hasil dari wawancara dan diskusi kelompok terarah, dan penyebaran kuesioner terbuka (bakhri, 2017) dengan cara mengorganisasikan data ke dalam kategori, menjabarkan ke dalam unit-unit, melakukan sintesa, dan membuat kesimpulan sehingga mudah dipahami, baik terhadap hasil instrumen matriks analisis SWOT. Penelitian ini menggunakan juga analisis SWOT, yang dilakukan untuk menggali atau mengevaluasi terhadap kekuatan, kelemahan, peluang, dan ancaman (Rangkuti, 2013) terhadap kondisi eksisting dalam menganalisis kekuatan para Pedagang Kaki Lima di tengah pandemic covid-19. Untuk memudahkan urutan prioritas dengan menggunakan analisis SWOT, maka penting dilakukan kualifikasi terhadap beberapa pernyataan narasumber terhadap faktor kekuatan, kelemahan serta tantangan dari masing-masing faktor yang diutarakan.

\section{KONSEP DASAR \\ Pedagang Kaki Lima}

Pedagan kaki lima merupakan sebuah komunitas pedagang, yang dalam aktivitas jualannya seringkali memanfaatkan area pinggir jalan raya. Mereka menggelar dagangannya, atau gerobaknya di pinggir perlintasan jalan raya. Dilihat dari sejarahnya di kegiatannya, sehingga dapat terjadi Indonesia, PKL sudah ada sejak masa penjajahan Kolonial Belanda. Pada masa Penjajahan kolonial, peraturan pemerintahan menetapkan bahwa setiap jalan raya yang dibangun hendaknya menyediakan sarana untuk para pedestrian atau pejalan kaki (sekarang ini disebut dengan trotoar). Lebar ruas untuk saranabagi para pejalan kaki atau trotoar ini adalah lima kaki. Pemerintahan padawaktu itu juga menghimbau agar sebelah luar dari trotoar diberi ruang yang agak lebar atau agak jauh dari pemukiman penduduk.

Ruang ini untuk dijadikan taman sebagai penghijauan dan resapan air. Dengan adanya tempat atau ruang yang agak lebar itu kemudian para pedagang mulai banyak menempatkan gerobaknya untuk sekedar beristirahat sambil menunggu adanya para pembeli yang membeli dagangannya. Seiring perjalanan waktu banyak pedagang yang memanfaatkan lokasi tersebut sebagai tempat untuk berjualan, sehingga mengundang para pejalan kaki yang kebetulan lewat untuk membeli makanan dari situ maka Pemerintahan Kolonial Belanda menyebut mereka sebagai Pedagang Lima Kaki (buah pikiran dari pedagang yang berjualan di area pinggir perlintasan para pejalan kaki atau trotoar yang mempunyai lebar Lima Kaki) (Astuti et al., 2017).

Komunitas pedagang kaki lima ini termasuk ke dalam komponen utama dari usaha mikro dan terlibat sebagai usaha sektor informal, namun dengan tantangan lingkungan yang masih kurang kondusif sehingga komunitas ini mengalami kesulitan dalam mengembangkan bisnisnya. Mengakibatkan kondisi umum pedagang kaki lima mengalami produktivitas dan daya saing yang relatif rendah. Pedagang kaki lima menjadi pekerjaan yang tersedia bagi anggota masyarakat yang berpendidikan rendah dengan pengalaman serta keterampilan yang sangat terbatas. Usaha kecil menjadi bagian tak terpisahkan dari kehidupan keseharian masyarakat di Indonesia maupun di belahan dunia pada umumnya. Usaha kecil sangat menunjang kemudahan hidup konsumen Indonesia dan berpengaruh sangat besar terhadap penciptaan lapangan kerja juga peningkatan pertumbuhan perekonomian suatu Negara (Zulhijahyanti et al., 2021).

Di sisi lain, pedagang kaki lima identik dengan masalah kemacetan lalu lintas dan kesemwarutan, karena kelompok pedagang ini memanfaatkan trotoar dan fasilitas umum lainnya sebagai media berdagang. Namun bagi sekelompok masyarakat, PKL justru menjadi solusi untuk 
mendapatkan barang dengan harga miring/murah.

Dengan kata lain di satu sisi keberadaan PKL dianggap menimbulkan berbagai masalah perkotaan, namun di sisi lain memiliki manfaat ekonomi bagi sebagian masyarakat. Menurut Pena (1999), terdapat tiga pilihan mengatasi PKL, pertama, negara harus menjadi kunci dalam mengatur PKL, karena keberadaan negara sangat penting dalam proses pembangunan, kedua, organisasi PKL dibiarkan untuk terus mengatur kegiatan mereka sendiri, ketiga, menyarankan pemerintah dan PKL untuk menegosiasikan ruang-ruang aksinya (lokasi usaha) (Astuti et al., 2017).

\section{Resiliensi Usaha}

Resiliensi menurut Benard dalam (Dewi Amaliah, 2020) dimaksudkan sebagai proses kebangkitan diri dari berbagai masalah dan tekanan kompetensi yang berupa social competence, problem solving skill, autonomy, dan sense of purpose. Papalia, Olds, dan Feldman (2001) mendefinisikan resiliensi sebagai sebuah sikap yang dimiliki seseorang tentang keuletan, tahan banting, tidak mudah menyerah dalam menghadapi masa-masa sulit. Sedangkan usaha menurut (Effendy, 2016) adalah kegiatan mengerahkan tenaga, pikiran, atau badan untuk mencapai suatu maksud; perbuatan, pekerjaan, prakarsa, ikhtiar, daya upaya untuk mencapai keuntungan dalam bidang perdagangan.

Maka dapat dipahami bahwasanya resiliensi usaha adalah suatu proses seseorang/ badan/ perusahaan atau pelaku usaha lainnya dalam bertahan dan membangkitkan usaha dari berbagai masalah dan tekanan kompetensi usaha yang ada agar tetap dapat memperoleh keuntungan. Pemilihan seseorang terhadap jenis usaha tentunya berdasarkan pada kompetensi orang tersebut, maka relisiensi ada pilihan sadar seseorang untuk dapat memilih jenis usaha yang sesuai dan menurut yang bersangkutan memiliki prospek dan berkesinambungan.

\section{Pandemi Covid-19}

Pandemi Covid-19 merupakan pandemiyang terjadi secara global (Bakhri \& Futiah, 2020) yang disebabkan karena munculnya virus bernama virus corona. Virus Corona yaitu zoonotic yang artinya ditularkan antara hewan dan manusia. yang biasanya menyerang saluran pernafasan pada mansuia dengan gejala awal seperti flu hingga dapat menyebabkan sindrom pernafasan akut berat (SARS). Penyebaran penyakit ini biasanya melalui pernafasan dari batuk maupun bersin. Berdasarkan Kementerian Kesehatan Indonesia, perkembangan kasus Covid-19 di Wuhan berawal pada tanggal 30 Desember 2019 dimana Wuhan Municipal Health Committee mengeluarkan pernyataan "urgent notice on the treatment of pneumonia of unknown cause" (Hanoatubun) dalam (Sarip et al., 2020). Virus ini menunjukkan penyebaran yang signifikan dan bahkan menyebabkan banyak kasus kematian pada berbagai negara di dunia termasuk Indonesia. Sampai pada kemudian pada tanggal 11 Maret 2020, WHO mengumumkan bahwa wabah yang sedang terjadi tersebut sebagai pandemic global (Yamali \& Putri, 2020).

Semua kalangan masyarakat ikut terdampak dengan adanya pandemic ini, diantaranya yaitu masyarakat yang terpinggirkan terutama masyarakat miskin yang ada di perkotaan, pekerja lepas, pekerja informal, dan pekerja sementara terkena dampak pandemi covid- 19 ini secara tidak proporsional (McKibbin dan Fernando, 2020). Kementerian keuangan menyampaikan mengenai covid-19 telah memberikan ancaman terhadap gangguan kesehatan dan ancaman terhadap kondisi kejiwaan dikarenakan resiko dari peningkatan kasus positif covid-19 hingga puluhan ribu jiwa per harinya, berdampak pada ancaman kehilangan pekerjaan terutama pada masyarakat yang tidak mampu dan keluarga yang bekerja dalam sektor informal. Kredit macet pada UMKM dikarenakan UMKM tidak dapat menjalankan usaha secara normal, sistem koperasi terganggu hingga kondisi perbankan yang dapat mengalami persoalan 
likuiditas, depresiasi rupiah, dan persoalain lainnya (Qiptiyah, 2021).

\section{Analisis SWOT}

Analisis SWOT merupakan salah satu teknik analisis yang berupaya mengenali kekuatan, kelemahan, peluang dan ancaman yang digunakan dengan tujuan merumuskan suatu strategi. Rancangan strategi dirumuskan dengan harapan memaksimalkan kekuatan dan peluang yang ada, namun secara bersamaan dapat meminimalkan kelemahan dan ancaman yang ada berdasarkan kondisi eksisting di lapangan. Menurut (Noor, 2014), bila strategi yang didapat berdasarkan analisis swot ini dapat diterapkan secara akurat, asumsi sederhana atas strategi tersebut dapat berdampak sangat besar karena berfungsi sebagai informasi yang dibutuhkan agar dapat mengidentifikasi peluang dan ancaman untuk pengembangan perusahaan kedepan.

Adapun unsur-unsur SWOT dalam (Fahmi, 2016) yang dianggap penting dalam analisis SWOT adalah : 1). Faktor eksternal, faktor ini menyangkut terkait dengan hal-hal diluar lingkungan perusahaan/ institusi yang berpengaruh terhadap pembuatan suatu keputusan. Pada analisis eksternal, faktor ini dibentuk oleh dua hal, yaitu opportunities dan threats $(\mathrm{O}$ dan $\mathrm{T})$, antara lain seperti: lingkungan industry dan bisnis makro, politik, hukum, perkembangan teknologi, kondisi social budaya, kependudukan. 2). Faktor internal, faktor ini menyangkut terkait hal-hal yang berasal dari dalam lingkungan perusahaan/institusi yang dapat mempengaruhi terbentuknya suatu keputusan perusahaan/institusi tersebut. Faktor ini dibentuk oleh Strenghts dan Weaknesses (S dan $\mathrm{W}$ ) yaitu meliputi manajemen fungsional perusahaan, seperti $R$ and $D$ perusahaan/institusi, seperti, kepemilikan sumber daya manusia, kepemilikan pada sistem informasi, system dan manajemen yang digunakanserta beberapa komponen sejenisnya.

\section{PEMBAHASAN DAN DISKUSI \\ Interaksi Faktor Intermal dan Eksternal Terhadap Penataan PKL di Kabupaten Cirebon}

Dalam analisis ini,kami mencoba memberikan bobot pada masing-masing item pernyataan yang diberikan sendiri oleh narasumber. Pemberian bobot diperlukan untuk mengukur agar pernyataan-pernyataan tersebut dapat di kualifikasikan dan mudah untuk melakukan penghitungan seberapa kuat dan lemah secara internal, dan seberapa peluang dan tantangan secara eksternal.

Analisis SWOT diperlukan untuk mengukur kekuatan dan kelemahan diri secara internal sesuai kondisi Eksisting terhadap perkembangan dan dukungan terlaksananya Penataan PKL di Kabupaten Cirebon hingga saat ini. Sementara itu secara eksternal, analisis terhadap opportunity dan threat juga diperlukan untuk mengetahui sejauh mana faktor-faktor eksternal tersebut mempengaruhi, dan sekaligus mendorong berjalannya kegiatan Penataan PKL (Pedagang Kaki Lima) sebagai sebuah usaha yang memiliki kesinambungan dan berkelanjutan (sustainable livelihood).

$$
\text { Melakukan analisis SWOT }
$$

didasarkan pada logika dengan memaksimalkan kekuatan (Strength) dan peluang (Opportunity), dan pada saat yang sama dapat meminimalkan kelemahan (Weakness) dan ancaman (Threat). Dengan mengetahui faktor internal yaitu kekuatan dan kelemahan, serta secara bersama juga mengidentifikasi faktor eksternal yaitu peluang dan ancaman.

Semua elemen dalam SWOT dijaring melalui jawaban beberapa narasumber terhadap pernyataan yang diajukan dalam kuesioner SWOT. Berikut ini hasil dari isian beberapa narasumber yang memiliki kompetensi pada pada pengembangan PKL. Kuesioner SWOT yang dilakukan pada narasumber yang dipandang memiliki pengetahuan yang cukup terhadap perkembangan sekaligus upaya dalam penataan PKL di Kabupaten Cirebon. 
Tabel 1.

Matrik Interaksi faktor Internal dan Eksternal Penataan PKL di Kabupaten Cirebon

\begin{tabular}{|c|c|}
\hline Faktor Internal & Faktor Eksternal \\
\hline $\begin{array}{l}\text { A. Kekuatan } \\
\text { (1) Penataan PKL menjadi prioritas } \\
\text { pembangunan daerah Kabupaten Cirebon } \\
\text { (2) Peningkatan kesejahteraan para PKL } \\
\text { (3) Terdapat peraturan daerah mengenai } \\
\text { PKL } \\
\text { (4) Alokasi anggaran untuk penataan PKL } \\
\text { (5) Terdapat Organisasi Perangkat Daerah } \\
\text { dalam menangani PKL } \\
\text { (6) Adanya lintas koordinasi dari lembaga } \\
\text { swasta, pemeritah dan masyarakat } \\
\text { (7) Sarana transportasi yang menunjang } \\
\text { mobilitas pemasaran } \\
\text { (8) Inovasi pemasaran yang menghampiri } \\
\text { konsumen secara langsung } \\
\text { (9) Kesempatan yang sama untuk } \\
\text { memanfaatkan perkembangan teknologi } \\
\text { digital }\end{array}$ & $\begin{array}{l}\text { C. Peluang } \\
\text { (1) Kebijakan pusat yang mendorong } \\
\text { penataan dan pemberdayaan PKL } \\
\text { (2) Perkembangan wisata di Kabupaten } \\
\text { Cirebon } \\
\text { (3) Perbaikan sistem sarana prasarana } \\
\text { perkotaan } \\
\text { (4) Lokasi yang strategis } \\
\text { (5) Keterlibatan swasta, akademisi dan } \\
\text { masyarakat } \\
\text { (6) Mendapat respon positif dari para } \\
\text { pelaku PKL } \\
\text { (7) Cirebon menjadi tempat transit/tujuan } \\
\text { wisata } \\
\text { (8) Berkembangnya teknologi informasi } \\
\text { (9) Akses untuk mengupgrade } \\
\text { pengetahuan dan pengalaman terbuka } \\
\text { lebar } \\
\text { (10) Pemenuhan kebutuhan masyarakat } \\
\text { saat kebijakan social distancing }\end{array}$ \\
\hline $\begin{array}{l}\text { B. Kelemahan } \\
\text { (1) Kurangnya pengawasan dan penegakan } \\
\text { aturan } \\
\text { (2) Minimnya tanda-tanda larangan } \\
\text { keamanan } \\
\text { (3) Kurang efektivitasnya penggunaan } \\
\text { anggaran } \\
\text { (4) Kurangnya kerjasama antara swasta, } \\
\text { masyarakat dan akademisi } \\
\text { (5) Minimnya kegiatan promosi } \\
\text { (6) Kurangnya koordinasi Organisasi } \\
\text { Perangkat Daerah yang belum maksimal } \\
\text { (7) Kurangnya pembinaan terhadap para } \\
\text { pedagang secara rutin } \\
\text { (8) Karakteristik atau pola pikir PKL } \\
\text { (9) Penataan PKL yang belum maksimal } \\
\text { (10) Kurangnya pengetahuan, kreativitas dan } \\
\text { inovasi dalam hal produksi dan } \\
\text { pemasaran } \\
\text { (11) Kegiatan distribusi yang terbatas }\end{array}$ & $\begin{array}{l}\text { D. Ancaman } \\
\text { (1) Meningkatnya pertumbuhan angka } \\
\text { pengangguran } \\
\text { (2) Adanya penolakan penertiban dari } \\
\text { para pelaku PKL } \\
\text { (3) Menurunnya estetika tata ruang kota } \\
\text { (4) Menambah titik kemacetan lalu lintas } \\
\text { (5) Pengembangan sistem sarana } \\
\text { prasarana yang tidak terintegrasi } \\
\text { (6) Munculnya oknum/premanisme } \\
\text { (7) Daya dukung penataan yang tidak } \\
\text { berkelanjutan } \\
\text { (8) Kebijakan pemerintah terkait } \\
\text { pencegahan penyebaran covid-19 } \\
\text { (9) Daya saing usaha yang kompetitif } \\
\text { (10) Penertiban satpol PP }\end{array}$ \\
\hline
\end{tabular}

Sumber: Data Primer diolah, 2020 
Selanjutnya setelah faktor-faktor dari kekuatan, kelemahan, peluang dan ancaman itu sudah ditetapkan kemudian dilakukan pembobotan dengan sebelumnya melakukan tabulasi terlebih dahulu dari jawaban beberapa responden.

Berdasarkan temuan lapangan, beberapa indikator yang menjadi kekuatan sekaligus mendorong dilakukannnya penataan PKL di Kabupaten Cirebon. Berdasarkan data tersbut, mayoritas responden mengatakan sangat setuju dengan pernyataan terkait kondisi eksisting dalam upaya penataan PKL di Kabupaten Cirebon. Dalam hal ini, hanya pada indikator adanya lintas koordinasi dari lembaga swasta, pemerintah dan masyarakat saja yang di nilai cenderung kurang setuju.

Beberapa indikator yang menjadi kelemahan penataan PKL di Kabupaten Cirebon. Berdasarkan data tersbut, mayoritas responden mengatakan sangat setuju dengan pernyataan terkait kondisi eksisting dalam upaya penataan PKL di Kabupaten Cirebon. Dalam hal ini, hanya pada indikator kurang efektifnya penggunaan anggaran penataan PKL yang di nilai cenderung kurang setuju.

Sedangkan beberapa indikator yang menjadi peluang sekaligus pendorong dilakukannnya penataan PKL di Kabupaten
Cirebon. Berdasarkan data tersbut, mayoritas responden mengatakan sangat setuju dengan pernyataan terkait kondisi eksisting dalam upaya penataan PKL di Kabupaten Cirebon. Dalam hal ini, hanya pada indikator keterlibatan swasta, akademisi dan masyarakat yang di nilai cenderung kurang setuju.

Adapun beberapa indikator yang menjadi ancaman dilakukannnya penataan PKL di Kabupaten Cirebon. Berdasarkan data tersebut, sebagian besar responden mengatakan setuju dengan pernyataan terkait ancaman dalam rangka upaya penataan PKL di Kabupaten Cirebon. Indikator ancaman tersebut munculnya oknum atau premanisme ditengah usaha PKL, dan mayoritas responden menyatakan tidak setuju adanya ancaman tersebut.

\section{Pembobotan Faktor Intermal dan Eksternal Terhadap Penataan PKL di Kabupaten Cirebon}

Dengan pembobotan bertujuan untuk mengetahui seberapa besar faktor-faktor yang mempengaruhi atau berdampak pada berjalanya Penataan PKL di Kabupaten Cirebon. Sehingga dapat diketahui pengaruh faktor tersebut terhadap berjalannya pada masing-masing kekuatan dan kelemahan.

Tabel 2.

Faktor Strategi Internal (IFAS) Penataan PKL di Kabupaten Cirebon

\begin{tabular}{|c|c|c|c|c|c|}
\hline \multirow[b]{2}{*}{ No } & Faktor Internal Dominan & \multirow[b]{2}{*}{ JUMLAH } & \multirow[b]{2}{*}{ RATING } & \multirow[b]{2}{*}{$\begin{array}{c}\text { BOBOT } \\
\%\end{array}$} & \multirow{2}{*}{$\begin{array}{c}\text { BOBOT } \\
\text { X } \\
\text { RATING }\end{array}$} \\
\hline & STRENGHTS & & & & \\
\hline 1 & $\begin{array}{l}\text { Penataan PKL menjadi prioritas } \\
\text { Pembangunan Daerah }\end{array}$ & 49 & 3 & 0,07 & 0,24 \\
\hline 2 & Peningkatan kesejahteraan PKL & 43 & 3 & 0,06 & 0,18 \\
\hline 3 & Terdapat peraturan daerah mengenai PKL & 45 & 3 & 0,07 & 0,20 \\
\hline 4 & Alokasi anggaran untuk penataan PKL & 40 & 3 & 0,06 & 0,16 \\
\hline 5 & $\begin{array}{l}\text { Terdapat Organisasi Perangkat Daerah } \\
\text { dalam menangani PKL }\end{array}$ & 40 & 3 & 0,06 & 0,16 \\
\hline 6 & $\begin{array}{l}\text { Adanya lintas koordinasi dari lembaga } \\
\text { swasta, pemerintah dan masyarakat }\end{array}$ & 34 & 2 & 0,05 & 0,12 \\
\hline & & 251 & & $\mathbf{0 , 3 8}$ & 1,06 \\
\hline
\end{tabular}




\begin{tabular}{|c|c|c|c|c|c|}
\hline No & WEAKNESSES & JUMLAH & RATING & $\begin{array}{c}\text { BOBOT } \\
\%\end{array}$ & $\begin{array}{c}\text { BOBOT } \\
\text { X } \\
\text { RATING }\end{array}$ \\
\hline 1 & $\begin{array}{l}\text { Kurangnya pengawasan dan } \\
\text { penegakan hukum }\end{array}$ & 48 & 3 & 0,07 & 0,23 \\
\hline 2 & $\begin{array}{l}\text { Minimnya tanda-tanda larangan } \\
\text { keamanan }\end{array}$ & 45 & 3 & 0,07 & 0,20 \\
\hline 3 & $\begin{array}{l}\text { Kurang efektifnya penggunaan } \\
\text { anggaran }\end{array}$ & 41 & 3 & 0,06 & 0,17 \\
\hline 4 & $\begin{array}{l}\text { Kurangnya kerjasama antara swasta, } \\
\text { masyarakat dan akademisi }\end{array}$ & 46 & 3 & 0,07 & 0,21 \\
\hline 5 & Minimnya kegiatan promosi & 49 & 3 & 0,07 & 0,24 \\
\hline 6 & $\begin{array}{l}\text { Koordinasi Organisasi Perangkat } \\
\text { Daerah yang belum maksimal }\end{array}$ & 45 & 3 & 0,07 & 0,20 \\
\hline 7 & $\begin{array}{l}\text { Kurangnya pembinaan terhadap para } \\
\text { pedagang secara rutin }\end{array}$ & 43 & 3 & 0,06 & 0,18 \\
\hline 8 & Karakteristik dan Pola Pikir PKL & 47 & 3 & 0,07 & 0,22 \\
\hline 9 & Penataan PKL yang belum maksimal & 52 & 3 & 0,08 & 0,27 \\
\hline & TOTAL & 416 & & 0,62 & 1,93 \\
\hline
\end{tabular}

Sumber: Data Primer diolah, 2020

Berdasarkan pada tabel 2.matriks IFAS diatas, terlihat bahwa faktor kekuatan dan kelemahan secara internal terkait Feasibility Study Penataan PKL di Kabupaten Cirebon. Dari pembobotan Faktor kekuatan dapat diperoleh skor sebesar 1.06, sementara skor kelemahan sebesar 1.93. Kalau dijumlahkan keseluruhan faktor internal sebesar 2.99. Nilai total diatas menggambarkan reaksi internal dari berjalannya penataan PKL di Kabupaten Cirebon hingga saat sekarang.
Sementara itu, pada tabel 3.matrik EFAS dibawah, terlihat bahwa faktor peluang dan ancaman secara eksternal terhadap Feasibility Study Penataan PKL di Kabupaten Cirebon. Dari Pembobotan Faktor peluang dapat diperoleh skor sebesar 1.91, sementara skor ancaman sebesar 1.05. Adapun jika keduanya dijumlahkan, maka dapat diketahui keseluruhan faktor eksternal sebesar 2.97. Nilai total diatas menggambarkan reaksi eksternal dari berjalannya Penataan PKL di Kabupaten Cirebon.

Tabel 3.

Faktor Strategi Eksternal (EFAS) Penataan PKL di Kabupaten Cirebon

\begin{tabular}{|c|l|r|r|r|r||}
\hline \hline \multirow{2}{*}{ No } & \multicolumn{1}{|c|}{ Faktor Eksternal Dominan } & \multirow{2}{*}{ OUMLAH } & RATING & $\begin{array}{c}\text { BOBOT } \\
\%\end{array}$ & $\begin{array}{c}\text { BOBOT } \\
\text { XPTUNITIES } \\
\text { RATING }\end{array}$ \\
\hline 1 & \multicolumn{1}{|c|}{$\begin{array}{l}\text { Kebijakan pusat men-dorong penataan } \\
\text { PKL }\end{array}$} & 46 & 3 & 0,08 & 0,23 \\
\hline 2 & $\begin{array}{l}\text { Perkembangan wisata di Kabupaten } \\
\text { Cirebon }\end{array}$ & 51 & 3 & 0,08 & 0,29 \\
\hline 3 & $\begin{array}{l}\text { Perbaikan sistem sarana prasarana } \\
\text { perkotaan }\end{array}$ & 54 & 4 & 0,09 & 0,32 \\
\hline 4 & Lokasi Kabupaten Cirebon yang strategis & 54 & 4 & 0,09 & 0,32 \\
\hline
\end{tabular}




\begin{tabular}{|c|c|c|c|c|c|}
\hline 5 & $\begin{array}{l}\text { Keterlibatan swasta, akademisi dan } \\
\text { masyarakat }\end{array}$ & 42 & 3 & 0,07 & 0,20 \\
\hline 6 & $\begin{array}{l}\text { Mendapat respon positif dari para } \\
\text { pelaku PKL }\end{array}$ & 44 & 3 & 0,07 & 0,21 \\
\hline \multirow[t]{2}{*}{7} & $\begin{array}{l}\text { Cirebon menjadi tempat transit/tujuan } \\
\text { wisata }\end{array}$ & 55 & 4 & 0,09 & 0,33 \\
\hline & & 346 & & $\mathbf{0 , 5 7}$ & 1,91 \\
\hline No & THREATS & JUMLAH & RATING & $\underset{\%}{\text { BOBOT }}$ & $\begin{array}{c}\text { BOBOT } \\
\text { X } \\
\text { RATING }\end{array}$ \\
\hline 1 & $\begin{array}{l}\text { Meningkatnya pertumbuhan angka } \\
\text { pengangguran }\end{array}$ & 40 & 3 & 0,07 & 0,18 \\
\hline 2 & $\begin{array}{l}\text { Adanya penolakan penertiban dari para } \\
\text { pelaku PKL }\end{array}$ & 37 & 2 & 0,06 & 0,15 \\
\hline 3 & Menurunnya estetika tata ruang kota & 41 & 3 & 0,07 & 0,19 \\
\hline 4 & Menambah titik kemacetan lalu lintas & 34 & 2 & 0,06 & 0,13 \\
\hline 5 & $\begin{array}{l}\text { Pengembangan sistem sarana prasarana } \\
\text { yang tidak terintegrasi }\end{array}$ & 38 & 3 & 0,06 & 0,16 \\
\hline 6 & Munculnya oknum/premanisme & 26 & 2 & 0,04 & 0,07 \\
\hline 7 & $\begin{array}{l}\text { Daya dukung penataan yang tidak } \\
\text { berkelanjutan }\end{array}$ & 40 & 3 & 0,07 & 0,18 \\
\hline & $\begin{array}{c}\text { TOTAL } \\
\end{array}$ & 602 & & $\mathbf{0 , 4 3}$ & $\mathbf{1 , 0 5}$ \\
\hline
\end{tabular}

Sumber: Data Primer diolah, 2020

Rekapitulasi Hasil Perhitungan Faktor Kekuatan, Kelemahan, Peluang dan Ancaman bagi berjalannya Penataan PKL di Kabupaten Cirebon

Berdasarkan hasil perhitungan yang telah dilakukan melalui analisis SWOT, didapatkan nilai akhir dari faktor faktor internal dan faktor eksternal. Hal tersebut bisa dilihat pada tabel 4.dengan perolehan sebagai berikut ;

Tabel 4.

Rekapitulasi Perhitungan Nilai Kekuatan, Kelemahan, Peluang dan Ancaman

\begin{tabular}{clc}
\hline No & \multicolumn{1}{c}{ Uraian } & Nilai \\
\hline 1. & Faktor Internal & \\
& Kekuatan & 1.06 \\
& Kelemahan & 1.93 \\
\hline 2. & Faktor Eksternal \\
& Peluang & 1.91 \\
& Ancaman & 1.05 \\
\hline \multicolumn{2}{l}{ Sumber: Data Primer diolah, 2020}
\end{tabular}

Berdasarkan pada hasil rekapitulasi terhadap kekuatan, kelemahan, peluang dan tantangan terhadap berjalannyaPenataan PKL di Kabupaten Cirebon, maka strategi terbaik berdasarkan SWOT adalah bagaimana memaksimalkan kekuatan dengan meminimalkan kelemahan sekaligus memaksimalkan peluang dengan meminimalkan ancaman

\section{Matriks SWOT}

Proses pengambilan keputusan strategis selalu berkaitan dengan pengembangan Visi, Misi dan Strategi serta kebijakan yang dibangun oleh Pemerintah daerah Kabupaten Cirebon. Setelah mendapatkan perhitungan faktor Internal dan faktor eksternal, kemudian merencanakan strategi-strategi untuk mewujudkan Penataan PKL yang dilakukan dengan menggunakan metode analisis SWOT, seperti dibawah ini ; 
Tabel 5.

Matriks Penataan PKL Kabupaten Cirebon

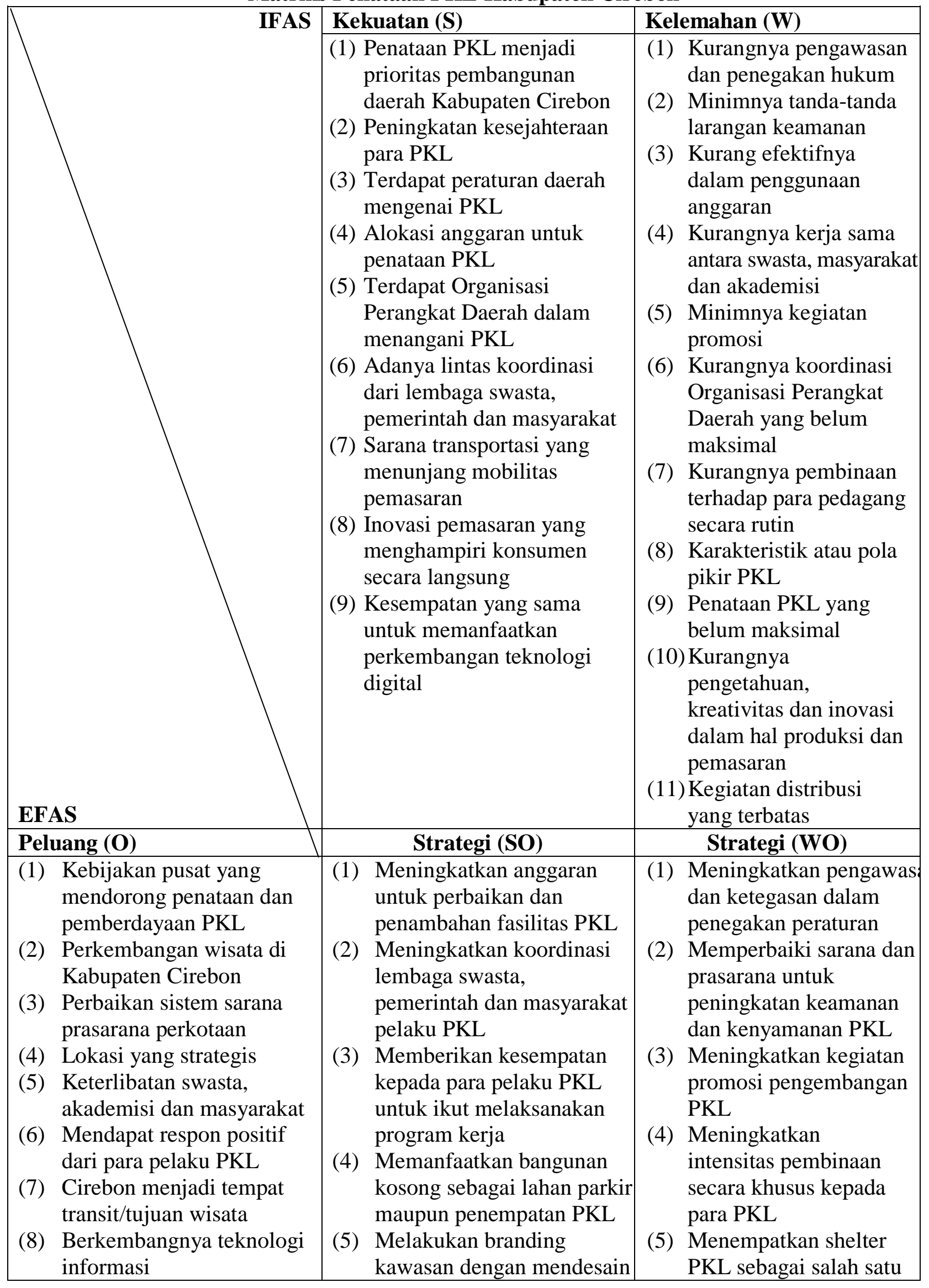




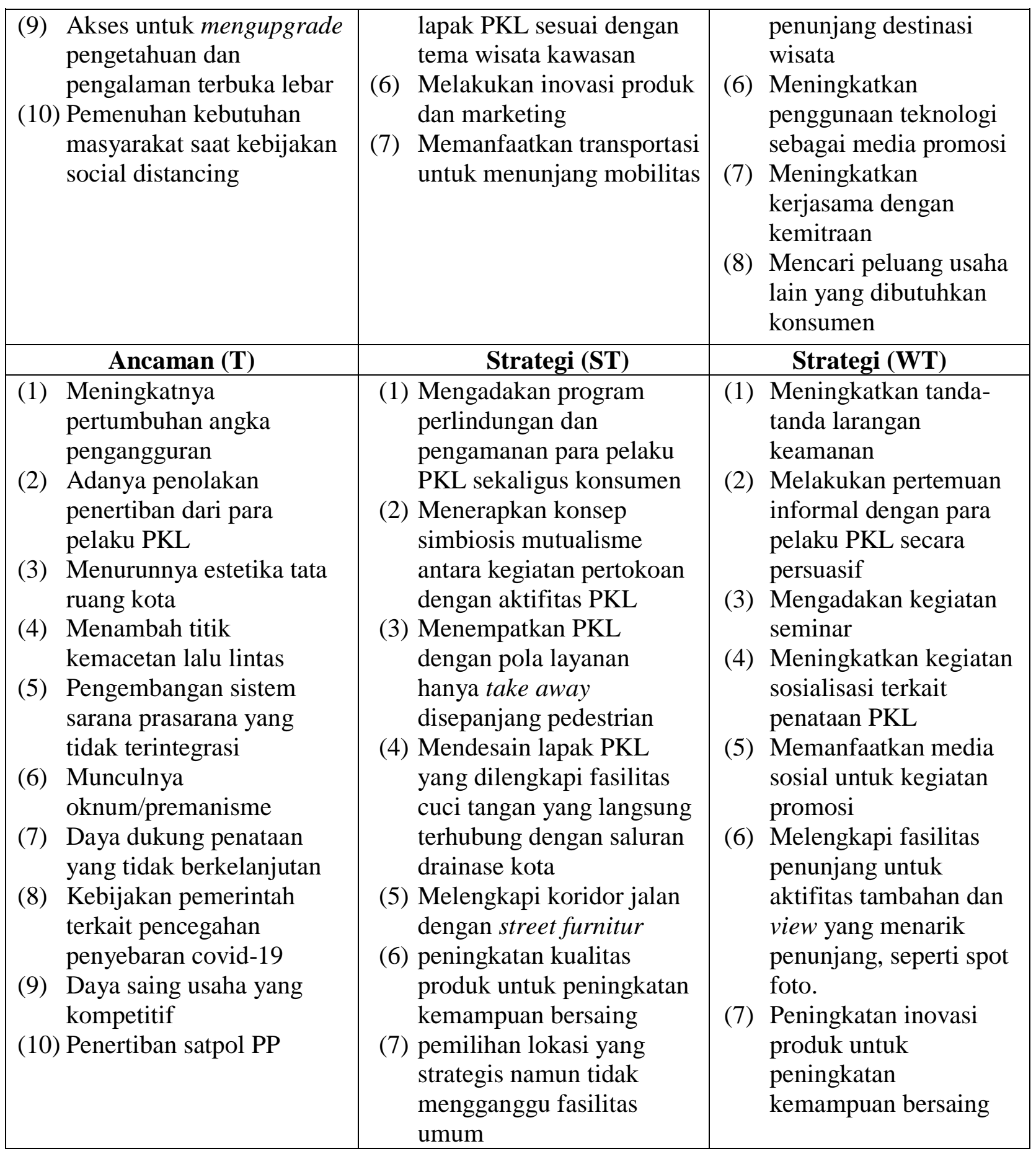

Sumber: Data Primer diolah, 2020

Hasil dari Matriks SWOT tersebut, secara ringkas dapat dilihat pada tabel 6.dibawah berikut ini ;
Tabel 6.

\section{Pembobotan Hasil Analisis SWOT}

\begin{tabular}{|c|c|c|}
\hline IFAS & $\mathrm{S}=1.06$ & $\mathrm{~W}=1.93$ \\
$\mathrm{O}=1.91$ & $\mathrm{SO}=2.98$ & $\mathrm{WO}=3.84$ \\
\hline $\mathrm{T}=1.05$ & $\mathrm{ST}=2.12$ & $\mathrm{WT}=2.99$ \\
\hline \multicolumn{2}{|c|}{ Sumber: Data Primer diolah, 2020}
\end{tabular}


Urutan Alternatif Strategi Penataan PKL di Kabupaten Cirebon

Berdasarkan Tabel 7. maka bisa disusun prioritas berdasarkan kombinasi strategi paling tinggi hingga strategi paling rendah. Urutan alternatif strategi bisa dilihat pada tabel dibawah ini;

Tabel 7.

Urutan Alternatif Strategi SWOT

\begin{tabular}{|c|l|c|}
\hline Prioritas & \multicolumn{1}{|c|}{ Strategi } & $\begin{array}{c}\text { Bobot } \\
\text { Nilai }\end{array}$ \\
\hline 1 & $\begin{array}{l}\text { Weakness - } \\
\text { Opportunity (WO) }\end{array}$ & 3.84 \\
\hline 2 & $\begin{array}{l}\text { Weakness - } \\
\text { Threath (WT) }\end{array}$ & 2.99 \\
\hline 3 & $\begin{array}{l}\text { Strength - } \\
\text { Opportunity (SO) }\end{array}$ & 2.98 \\
\hline 4 & $\begin{array}{l}\text { Strength - Threath } \\
\text { (ST) }\end{array}$ & 2.12 \\
\hline
\end{tabular}

Sumber: Data Primer diolah, 2020

Berdasarkan tabel 7.pada alternatif strategi hasil analisis SWOT menyatakan bahwa strategi Weakness- Opportunity (WO) memiliki nilai yang paling tinggi dibandingkan dengan strategi yang lain. Strategi yang dimaksud adalah bagaimana meminimalkan kelemahan dengan memanfaatkan peluang untuk mendukung berjalannya Penataan PKL di Kabupaten Cirebon.

\section{KESIMPULAN}

Berdasarkan temuan hasil penelitian dan analisis yang telah dilakukan, dapat ditarik kesimpulan bahwa dalam kenyataannya PKL di Kabupaten Cirebon tumbuh dan berkembang secara mandiri, sehingga penataan PKL perlu dukungan pemerintah daerah melalui strategi regulasi terkait penataan dan pemberdayaan yang implementasinya perlu lebih tegas untuk meminimalisasi kelemahan dengan memanfaatkan peluang sumber daya yang ada pada PKL itu sendiri. Untuk mengefisiensikan pemanfaatan ruang Kota Sumber sebagai pusat pemerintahan Kabupaten Cirebon, maka diperlukan upaya penataan PKL kedalam satu atau lebih dari satu lokasi penampungan PKL yang bisa mengakomodir dari pusat-pusat PKL eksisting dan sekitarnya.

Untuk menjaga eksistensi usaha para pelaku PKL di tengah masa pandemic covid19, para pelaku PKL dapat melakukan upgrade pola layanan yang disesuaikan dengan kondisi pemberlakukan kebijakan social distancing oleh pemerintah, seperti halnya penyediaan take away disepanjang pedestrian, pemanfaatan teknologi informasi sebagai sarana inovasi pemasaran agar dapat bersaing dengan persaingan yang semakin kompetitif.

\section{DAFTAR PUSTAKA}

Astuti, P., Asteriani, F., Sulaiman, M., \& Putri, T. A. (2017). Menemu-Kenali Karakteristik Pedagang Kaki Lima (Pkl) Di Jalan Kaharuddin Nasution Kota Pekanbaru. Prosiding Konferensi Nasional Teknik Sipil Dan Perencanaan (KN-TSP) "Inovasi Teknologi Smart Building Dan Green Construction Untuk Pembangunan Yang Berkelanjutan," 299-309.

Astuti, P., \& Qalyubi, I. (2021). Strategi Mempetahankan Keberlanjutan usaha Pedagang Kaki Lima di Masa Pandemi Covid-19 di Palangka Raya. Jurnal DAUN LONTAR, 1, 254-291.

Bakhri, S. (2017). Analisis Strategi Peningkatan Daya Saing Pasar Tradisional dalam Menghadapi Keberadaan Pasar Modern di Kabupaten Cirebon. EKOREGIONAL, 12(1). 23-31.

Bakhri, S., \& Futiah, V. (2020). Pendampingan dan Pengembangan Manajemen Pemasaran Produk UMKM Melalui Teknologi Digital Di Masa Pandemi Covid-19. Jurnal Loyalitas Sosial: Journal of Community Service in Humanities and Social Sciences, 2(2), 59. https://doi.org/10.32493/jls.v2i2.p5970

Budi, K. (2016). Penataan Pedagang Kaki Lima Di Aloon-Aloon Kabupaten Jombang. Jurnal Cakrawala, 10, 113124. 
Dewi Amaliah. (2020). Resiliensi Usaha Mikro, Kecil , Menengah (UMKM) dan Kebijakan Pemerintah di Masa Pandemi Covid 19. Utilitas, 6(2), 1-8.

Effendy, M. (2016). Kamus Besar Bahasa Indonesia Edisi Kelima. Kementerian Pendidikan dan Kebudayaan Republik Indonesia.

Fahmi, I. (2016). Kewirausahaan (Teori, Kasus dan Solusi) (Asakir (ed.); Cetakan ke). CV. Alfabeta.

Hutasuhut, I. M. (2020). Nasib PKL Di Tengah Pandemi Covid-19. http://repository.uma.ac.id/handle/1234 56789/12095

Indah, M. Y. N., Wulandari, R., Yanti, M. M., \& ... (2021). Resiliensi Wirausaha Digital di Masa Pandemi Covid-19: Studi Literatur. Proceeding of The ..., 1 , 643-648.

http://repository.urecol.org/index.php/p roceeding/article/download/1402/1369

Komara, B. D., Setiawan, H. C. B., \& Kurniawan, A. (2020). Jalan Terjal UMKM dan Pedagang Kecil Bertahan di Tengah Pandemi Covid-19 dan Ancaman Krisis Ekonomi Global. Jurnal Manajemen Bisnis, 17(3), 342. https://doi.org/10.38043/jmb.v17i3.250 6

Mashudi, R., Hutagaol, M. P., \& Hartoyo, S. (2019). Strategi Penataan Pkl Di Jalan Dewi Sartika Kota Bogor. Jurnal Manajemen Pembangunan Daerah, 6(2), 51-61. https://doi.org/10.29244/jurnal_mpd.v6 i2.25100

Noor, S. (2014). Penerapan Analisis SWOT Dalam Menentukan Strategi Pemasaran Daihatsu Luxio Di Malang (Studi Kasus Pada PT. Astra International Tbk. Daihatsu Malang). Jurnal INTEKNA, 17(2), 102-209.

Pratama, B. C., Innayah, M. N., \& Darmawan, A. (2021). Pendampingan Umkm Dan Pedagang Kaki Lima (PKL) Terdampak Pandemi Covid-19 Di Area Kampus Universitas Muhammadiyah Purwokerto Dalam Menjalankan Contactless Business. Jurnal Budimas,
$3(1), 116-122$.

Qiptiyah, M. (2021). Siasat Pedagang Kaki Lima di tengah Pandemi Covid-19 di Pasar Porong Kabupaten Sidoarjo. Jurnal Kajian Masalah Sosial, Juni(1), $1-19$.

http://dx.doi.org/10.1016/j.ndteint.2014 .07.001\%0Ahttps://doi.org/10.1016/j.n dteint.2017.12.003\%0Ahttp://dx.doi.or g/10.1016/j.matdes.2017.02.024

Sarip, Syarifudin, A., \& Muaz, A. (2020). DAMPAK COVID-19 TERHADAP PEREKONOMIAN MASYARAKAT DAN PEMBANGUNAN DESA. AlMustashfa: Jurnal Penelitian Hukum Ekonomi Islam, 5(1), 10-20. http://dx.doi.org/10.1016/j.ndteint.2014 .07.001\%0Ahttps://doi.org/10.1016/j.n dteint.2017.12.003\%0Ahttp://dx.doi.or g/10.1016/j.matdes.2017.02.024

Syariah, A., \& Widiastuti, M. A. (2017). Strategi Penataan Aktifitas Parkir dan Pedagang Kaki Lima pada Koridor Komersial Kota. EMARA: Indonesian Journal of Architecture, 3(1), 43-52. https://doi.org/10.29080/emara.v3i1.14 1

Usman, S. (2006). Pembangunan dan Pemberdayaan masyarakat. Pustaka Belajar.

Widjajanti, R. (2016). The space utilization by street vendors based on the location characteristics in the education area of Tembalang, Semarang. Procedia Social and Behavioral Sciences, 227, $186-193$.

Wiweka, K., Yulianti, Adnyana, P. P., \& Trisdyani, N. L. P. (2018). Analisis Ruang Komersial Bagi Pedagang Kaki Lima Di Kawasan Hutan Kota Rawa Dongkal, Kelurahan Cibubur, Jakarta Timur. Jurnal Sains Terapan Pariwisata, 3(3), 409-419. http://www.journal.polteksahid.ac.id/in dex.php/jstp/issue/view/jstp33/jstp33

Yamali, F. R., \& Putri, R. N. (2020). Dampak Covid-19 Terhadap Ekonomi Indonesia. Ekonomis: Journal of Economics and Business, 4(2), 384-388. https://doi.org/ 10.33087/ekonomis.v4i2.179 
Zulhijahyanti, H., Safira, K. A. A., Saputri, L. L., \& Permana, E. (2021). Strategi Mempertahankan Usaha Pedagang Kaki Lima (Pkl) Di Masa Pandemi Covid19. Inovasi: Jurnal Ilmiah Ilmu
Manajemen, 8(1), 21-29. http://www. komunitasdaunlontar.or.id/ojs.komunit asdaunlontar.or.id/index.php/jkdl/articl e/view/116 